\title{
PROMOTING GRAMMATICAL AWARENESS IN ENGLISH LANGUAGE TEACHING: ESP CONTEXT
}

\author{
Milawati \\ Politeknik Negeri Madura \\ e-mail:milawati@poltera.ac.id
}

\begin{abstract}
Recently, English Specific Purposes is taking a crutial issue to be considered. Since the implementation of ESP is apropriate to the need of its studies, the English skills which required by students is getting growth. Indeed, grammar as one of language components which supports the language skills also changing as its usage. However, the implementation of the grammar usage in ESP, is not really proper to its context. This paper presents the possibilities factors behind its unproper usage and also some activities which raises students' grammar awarenes. By knowing more about those issue will not only help the teacher to lead the students more effectively and properly in using the grammar, but it will also provide the teacher with a means of evaluating the teaching learning process and help the teacher to produce activities that will actually motivate the students to learn.
\end{abstract}

Keywords: Grammatical Awareness, ESP, English Language Teaching 


\section{INTRODUCTION}

Grammar plays significant roles in English as second language or foreign language. It takes a basic part in expressing spoken language, especially in productive skills. In addition to its role, grammar makes learners easier to comprehend sentence which is interrelationship to a paragraph, a passage, and a text. In case of writing skill, grammar allows learners to communicate in a written form. To reach the ability in these skills, the learners should learn about grammar as their basic of language use. Particularly, it has functioned as a formal study of language structure to fit words together in order to be able to construct a meaning (Williams, 2005:2).

In the context of EFL Teaching grammar, it is regarded as system of a language. Even, people sometimes describe grammar as the rules of a language. Grammar expands its distinction in EFL teaching context. In consequence, grammar is too important to be ignored because with grammar, learners' language development will be controlled (Richards and Renandya, 2002:145).

Despite, the importance of grammar in EFL teaching, some previous studies have noted a contratry condition among experienced EFL teacher. In this case, those who have higher capability in the four language skills, do not have any guarantee that their grammatical ability will be the same as other language skills capability. Because, sometime they still found many mistakes in their grammar when they teach their students. As Gozali \& Harjanto (2014) in their study of grammatical awareness in the context of EFL kindergarten teacher mentioned that most of students in one particular private kindergarden school has higher speaking ability,but lack in grammatical competence. In different language skills, such as reading skills, there was also found that students grammatical awareness could affect students' reading outcome (Su'ib, 2009; Jafari \& Rad, 2016).

\section{Type and Source of Grammatical Errors}

It is suggested to know the type and the source of the errors which made by the students in doing grammatical tasks. There are two types of errors according to Dulay, Burt \& Krashen (1982:191); global errors and local errrors. Global errors refer to the errors which could affect the whole sentence organization. This type of errors commonly found in students' tasks like misordering, misformation and regularization in transformational terms. While, the later error, accordingly, refers to the errors which affects single elements in a sentence and do not significantly barries in communicating.

In case of comparative taxonomy, the errors made by children when learning their target language, then, is compared to equivalent phrases and sentences in their mother tongue. It is classified into three types of errors; developmental error, interlingual error and ambigous error (Dulay, Burt \& Krashen, 1982:164). Developmental error is found commmonly in earlier stages of acquisition, exactly, when target language is learned as first language. Meanwhile, the L2 errors which reflect their native language structure are called as interlingual errors. The last error is the error which is found in children speech when they acquired their L1 is called as ambigous error. In more specific way, based on the surface strategy taxonomy, it is classified into ommission error (caused by a missing item which must appear in a well construction utterance), addition error (caused by an additional item which make the utterance becomes inappropriately), misformation error (caused by wrong form of morpheme or structure) and misordering error (caused by morpheme or group of morpheme which is inappropriate place in an utterance) in grammatical context. 


\section{Explicit Knowledge to Raise Grammatical Awareness}

Raising teacher grammatical awareness is not an easy process. Teacher should have acquired appropriate understanding of grammar knowlege. In order he/she can judge whether or not their students' works are correct. Related to the grammar knowledge, teacher's explicit knowledge of grammar is a need which enables them to teach effectively in either productive or receptive skills (Andrews, 2007; Su'ib, 2009; Jafari \& Rad, 2016). Explicit knowledge refers to the knowledge about grammar by unsderstanding the rule. In that way, the learner will be aware of what they have learned and they can also internalize and explain verbally of what they have learned (Ellis et al, 2009:3). Further, Ellis suggested two key points to become the explicit knowledge is useful. First, monitoring what the students have already said and wrote. In this case, the teacher could correct students' errors because the implicit knowledge is not acquired yet. Indeed, learners could get its benefit to acquire the implicit knowledge as well. Another suggestion is by noticing, they will be more likely to notice how a grammatical feature works, especially when they are listening or reading.

Regarding to teaching grammar, Ellis (2002) draws three different perspective, from the acquisition theory, the learner and the pedagogical perspective, in order to give arguments related to teaching grammar. From the perspective of acquisition theory, Ellis, then, mentions some possible reasons why learners failed to achieve a higher level of grammatical competence including learner's age, the number of communication within the learners and the teacher, their lack of opportunities to drill their output, and their lack of negative feedback. Differently, in the learner's perspective, explicit rule of the grammar is easier to understand rather than the implicit grammar. In that way, they are more likely to function the grammar as a means to communicate, and their ignorance to get the benefit from the grammar instruction. Lastly, from the side of pedagogical perspective, a syllabus which provide both teachers and learners with a clear sense of progression,is needed to involve in curriculum.

\section{Teaching Grammar Activities}

In relation to explicit knowledge, teacher can teach that knowledge in traditional way or through grammar discovery approach. As Fachrurrazy, (2011:95-97) suggested the teacher to teach certain grammar points in the pre activity of teaching when it is predicted that the students will face difficulties in skill activities. In post activity, teachers correct the errors by sparing some time before the class ends when teacher find grammar errors during the skill activities. Various activities can be used for teaching grammar.

a) Using deductive procedure, include: introducing the rule or formula, giving examples and doing exercises. The following example describes teacher wants to make the learners understand in using subject, be, and noun by giving the rules first, then it is followed by examples:

$\begin{array}{lll}\text { Rule } & : & \text { Subject }+ \text { Be }+ \text { Noun } \\ \text { Example }: & \text { I am a teacher } \\ \text { Exercise }: & \text { She_a student } \\ & & \end{array}$

I am a 
b) Using inductive procedure. In this case, the teacher could give examples first, then doing exercises in which the learners formulate the rule by themselves through the exercises given by the teacher, and end by making generalization. This procedure is often called as discovery learning.

c) Doing a form-focused activity for reinforcing a certain point of grammar. teacher can ask student to describe, write, or talk something that is related to the topic or tenses focused.

d) Using mechanical drills such as Repetition, simple substitution, multiple substitutions, substitution in variable positions, substitutions that must be changed, correlation drill, substitution that force a change, transformation drill, joining sentences, and expansion drill. For example:

- Simple substitution drill:
Teacher : She is a student
Students : She is a student
Teacher : a secretary
Students : She is a secretary
- Substitution in variable positions:
Teacher : He goes to school on foot
Students : He goes to school on foot
Teacher : We
Students : We go to school on foot
Teacher : by bicycle
Students : We go to school by bicycle

e) Using meaningful drill with visual aids, include real object, pictures, index cards, symbols, words. For example:

Teacher : (Pointing to a ruler) I have a ruler

Students : I have a ruler

Teacher : (point to a book)

Students : I have a book

f) Using meaningful drill with situational contexts, include classroom context, roleplay, imaginary, fantasy context, for example:

Teacher : Please ask him his name

Student A : What is your name?

Student B : My name is

g) Using meaningful drill in the form of conversation, include question-answer or stimulus-response, for example:

Teacher : What time is it now?

Students : It's ___ (half past seven)

Teacher : It's very warm in this room

Students :__ (Shall I open the window?) 
h) Other activities for grammar exercise can be completion, matching, and true-false, multiple choice, or grammar composition.

\section{Grammar Translation Method As One of Alternatives to Build Students' Explicit Knowledge}

Another activities to build EFL students' explicit knowledge could be taught through Grammar-Translation Method (GTM). Brown (2001:18-19) mentions some principal characteristics of GTM involve:

Mother tongue is dominantly used rather than learners target language. The teacher uses the native language to help student to understand the material given in grammar lesson. For instance, English teacher in Indonesia uses Indonesian for her/his instruction. Target language is a part of translation. The position of mother tongue is as same as their first language which is used to explain new grammatical concepts and to enable the students to compare what they have already understood dealing with the grammatical concepts in foreign language and their mother tongue.

Lists of isolated words are used to teach vocabulary. Teacher introduces some part of speech like verb, adjective, adverb, article, preposition, etc, related to a topic focused. Then, ask the students to translate them into English or the teacher writes some Indonesian words and asks the students to translate them into English.

Long explanation is used to internalize the grammatical concepts easily. Teacher could explain the definition and the rules of grammar such as definition of noun, verb, adjective, preposition, classification of noun or other parts of speech, how to change singular into plural nouns, present into past forms of verbs, active into passive voice.

The grammatical rule functions to fit words together. Students have to memorize the rule of subject, predicate, object, and complement. Then, it is explained by teacher to the students.

Classical text reading is taught early. Classical texts in this case, could refer to reading texts which are taken from old literary work, such as from Shakespeare. Teacher can also give other literary texts material from other classical authors. This characteristic can be implied earlier, even for the beginner class.

The exercises is not merely focused on content of text. In reading class, students are introduced to a reading text, which is analyzed grammatically. For example, students are asked to find the subject or predicate in each sentence, and asked to change the tenses (from present into past tense). This activity can enlarge the students' knowledge through the change of tenses.

Drill is a key point to connect students' target language and their mother tongue. Students are asked to translate the sentences into Indonesian, or other way around. In Grammar Translation Method (GTM), teacher often asks students to translate sentences directly for practicing translation and learning the application of tenses at once. For example: (the teacher may write on board)

The pencil is on the table

The woman standing there is my aunt

The sun rises in the east

Pronunciation is ignorance. It is not a prior goal in teaching grammar, the goal is they can use the grammar features appropriately. 


\section{CONCLUSION}

Although, raising grammatical awareness is not an easy way, it is a need for both teacher and students to acquire the appropriate knowldge of how grammar works. Through explicit knowledge, it is hoped that the students will be easier to internalize the grammatical concepts, and could monitor and notice their own mistakes in doing grammatical tasks. Finally, the teacher could set up grammar teaching activities which is mainly based on the students' current input. Hence, both teacher and students could have strong sensitivity toward the grammatical works.

\section{REFERENCES}

Andrews Stephen. (2007). Teacher Language Awareness. Cambridge: Cambridge University Press

Brown, H. Douglas. (2001). Teaching by Principles an Interactive Approach to Language Pedagogy 2nd ed. London : Pearson ESL Addison-Wesley Longman

Dulay Heidi, Burt Marina \& Krashen Stephen. (1982). Language Two. Oxford: Oxford University Press.

Ellis et al. (2009). Implicit and Explicit Knowledge in Second Language Learning, Testing and Teaching 2nd ed. Toronto : Multilingual Matters

Ellis Rod. (2002). The Place of Grammar Instruction in the Second/Foreign Language Curriculum. In E. Hinkel \& S. Fotos New Perspectives on Grammar Teaching in Second Language Classrooms (pages 14-34). Routledge: London.

Fachrurrazy. (2011). Teaching English as a Foreign Language for Teachers in Indonesia. Malang: State University of Malang Press

Jafari, Aliye Mohammad \& Rad, Neda Fatehi. (2016). The Influence of Phonological and Grammatical Awareness on EFL Students' Reading Performance. Journal of Language Teaching and Research Vol. 7 No. 6 pp. 116-1173. DOI://http://dx.doi.org/10.17507/jltr.0706.14

Gozali, Imelda \& Harjanto, Ignatius. (2014). Improving The grammatical accuracy of the spoken english of indonesian international kindegarten students. TEFLIN Journal Vo. 25 No. 2 July ISSN. 0215-773 X.pp. 168-184

Richards, Jack. C. and Renandya, Willy.A., 2002. Methodology in Language Teaching an Anthology of Current Practice. New York: Cambridge University Press

Su'ib, Munir. (2009). Grammmatical Awareness Among Primary School English Language Teachers. GEMA Online Journal of Language Studies Vol. 9 (1) pp. 35-46 ISSN. 1675-8021

Williams, James. D. 2005. The Teacher's Grammar Book 2nd ed. New York: Lawrence Erlbaum Associates 